\title{
Aplication Multi Vegetation Index to Mapping Magrove Distribution Coast Environtment Northeast Province of Aceh, Indonesia
}

\author{
Muhammad Hanif ${ }^{1)}$ and Tommy Adam ${ }^{2}$ \\ 1) Graduate of Geography Department, Faculty of Social Science, Universitas Negeri Padang, Indonesia \\ 2) Student of Geography Department, Faculty of Social Science, Universitas Negeri Padang, Indonesia \\ hanif12jhenif@gmail.com tommieadammaster@gmail.com
}

\begin{abstract}
The mangrove such forest very important at coastal ecosystem and environment. The purpose of the research to mapping mangrove distribution at the coast environment using multi vegetation index, comparison accuracy assessment to mapping mangrove area. The method of the research use by multi imagery transformation as NDVI, Infrared II, SAVI, EVI and Maximum Likelihood. Data on the research have using by Landsat OLI8, tools use by ENVI 5.0 and ArcGIS 10.1. Optimizing the used of data from Landsat satellite imagery for mapping mangrove found where sharper appearance mangrove area in the gray scale image of the results of the analysis of vegetation transformation NDVI, Infrared II, SAVI and EVI showing difference specification, but also found has founded difference objects of interpreted it was showing like shadows of cloud be the another object. To classification on mangrove object is seen from the results of density slicing of transformation value to classing vegetation. The percentage accuracy of image prove some dominant image transformation is able to indicate a more optimal mangrove and mangrove separating the object is not present, but the accuracy of the data analysis result has variations, refers to the number of samples used.
\end{abstract}

Keywords: Mapping Mangrove, Costal Environment, Remote Sensing

\section{Introduction}

Mangrove such characteristic of costal vegetation, estuary, delta at the place protecting of tropic and sub tropic (Mulyadi,et al., 2010). The as ecosystem where between land and ocean, mangrove have ecologic function the very important. Ecological function it can do look at some aspect, there physical, chemistry, and biologic. Physical aspect include of the ability to muffle the wave of the beach, holding on the mud and protecting of the costal system from abrasion. Then if looking from chemistry the act to absorption pollution of the water, as energy sources, and to be production for organic material. In the biological aspect, mangrove have position very important breed, looking of eat, and protected, and develop many kinds biota TNC and P4L (Forestian, 2011). The high deposits of $\mathrm{C}$ per hectare and their distribution throughout the tropics (total area of 14 million ha; referral 4,6) indicates that the mangrove is a store $\mathrm{C}$ on the surface of globally important. Although the examples in our study did not fully represent all kinds of mangrove (make this data can not be directly applied broadly), certain constraints on deposit global $\mathrm{C}$ can be obtained by combining a range of uncertainty of the empirical data we (the 5th percentile up to all - 95 of the value of deposits C) with additional global data on soil C content, depth and biomass (Donato, 2012).

Edmun P (2002) Mangrove areas are often difficult to reach and equally difficult to penetrate. Thus, field survey of mangroves is logistically demanding particularly where the areas are large. Remote sensing offers a very cost-effective method of extending limited field survey to map large areas of mangroves. Mangrove habitat maps are primarily used for three management applications: resource inventory, change detection and the selection and inventory of aquaculture sites. Analysis a range of remote 
sensing approaches to mangrove mapping and the quantitative assessment of mangrove resources using satellite and airborne imagery, and make recommendations as to the most effective options. Image processing techniques appropriate for mangrove mapping can be categorised into five main types: 1) visual interpretation, 2) vegetation indices, 3) unsupervised classification, 4) supervised classification, and 5) principal components analysis of band ratios. The image processing method (5) based on taking ratios of different red and infrared bands and using these as inputs to principal components analysis (PCA) generated the most consistently accurate maps of mangroves,

Mangrove inventory and mapping This has been the main use of remote sensing and has sought to answer general questions such as 'what area of mangrove is present in this area and how are different mangrove habitats distributed?'The end-product has usually been a mangrove habitat map (e.g. Vibulsresth 1990, Palaganas 1992, Vits and Tack 1995), occasionally with supplementary quantitative information such as tree height (Gray et al. 1990). Mangrove habitats have been commonly described by dividing mangrove areas into 2-7 categories which are named according to dominant or characteristic species. Category names such as 'Bruguiera zone'must be clearly defined (i.e. the percent composition of Bruguiera and associated species should be quantified) if users need to interpret maps in the field. Although a habitat may be labelled using a species or genus name, this does not mean that remote sensing enabled the analyst to identify individual mangrove trees belonging to that genus. The term is simply used as a label. Similarly when mangrove classes are described by assigning a qualitative measure of a particular mangrove characteristic (e.g. 'high', 'medium' and 'low' density or 'tall' and 'low') a user does not know how dense or how tall. Such maps have great descriptive value but cannot be used quantitatively. A few studies have obtained quantitative measurements of mangrove height (Gray et al. 1990) and height, density and species composition (Green et al. 1998, Edmun P, 200).

\section{Method}

Study Area

The study area at The northeast costal environment Province of Aceh, some location at mangrove area many people developed area and had using the land to other function, and the mangrove always be a target to developing area, like the farming area and tourism. The one of all location include at northeast costal environment Province of Aceh Langsa City, the government developing the mangrove area to be tourism object, and many people choosing the location to be destination at ecological tourism object. One of sides the police by the government giving good impact cause the tourism business will give economic benefit to build up economic capital, but on the one sides human activity at the mangrove area when the tourism object have been opening, it's will influence the gravitation land use changes around tourism object. Many factor will influence land use change around mangrove area. In the other place many people changes the mangrove area to be farming area such cultivate area like as rice and developing to fishpond surrounding of mangrove. The study area, include in three administration, it is Aceh Tamiang, Eastern of Aceh, and Langsa. At the shoreline that mangrove habitat will do interpretation to mapping mangroves. The materials in the research, Administration Map (BIG) Minister of Geospatial, Landsat TM and Landsat OLI 8 TIRS (USGS) United State Geology Surfaces, Spot Imagery, and the tools using ENVI 5.0 and ArcGIS 10.1. Main image processing techniques for mangroves. Analysis of the literature reveals that the approaches taken to classify remote sensing data on mangroves fall into five methodological groups.

\section{Vegetation Indices}

For to mapping mangrove use the vegetation indices in this research sue multi transformation. The use of vegetation indices in the remote sensing of mangroves. Vegetation indices are complex ratios involving mathematical transformations of spectral bands. As such vegetation indices transform the information from two bands or more into a single index. The normalised difference vegetation index or 
NDVI, Infrared II, NDSI, EVI, is a vegetation index. It is calculated from red and infra-red bands: middle Mathematically, NDVI is a simple ratio of two linear combinations of spectral reflectance values of NIR and red bands.

$$
\text { NDVI }=\frac{\text { Near Infrared }- \text { red }}{\text { Near Infrared }+ \text { red }}
$$

Vegetation index Infrared II, where developing from vegetation index NDVI, in the technic use band such difference by the NDVI, the formula (Danoedoro, 2012):

$$
\text { Infrared } I I=\frac{\text { near infrared }- \text { Middle infrared }}{\text { near infrared }+ \text { Middle infrared }}
$$

Soil adjusted vegetation index, SAVI, that such vegetation index to pressure the soil influence to spectral and reflect.

$$
\text { SAVI }=\frac{1.5 *(\text { Near Infrared }- \text { red }}{(\text { Near infored }+ \text { red }+L)}
$$

The usual $\mathrm{L}$ have value 1 for vegetation high density and 0.5 for vegetation low density. Enchance Vegetation Index EVI In addition to the NDVI product, MODIS VI products also include a newly developed enhanced VI (EVI) (Huete et al. 2002),

$$
E V I=G \frac{(\rho N I R-\rho R E D}{(L+C 1 x \text { pred }- \text { pblue }+L}
$$

Where $G$ is the gain factor, $C 1$ and $C 2$ are aerosol resistance coefficients, and $L$ is the canopy background adjustment. The numeric values for these coefficients are 2.5, 6.0, 7.5, and 1.0, respectively (Huete, Justice, and Liu 1994; Liu and Huete 1995). Compared to NDVI, EVI provides improved sensitivity of vegetation signals in high biomass or dense forest regions (Huete et al. 2002). The EVI is also better correlated with tree canopy structure characteristics such as LAI (Gao et al. 2000; Weng. 2011).

\section{Maximum likelihood decision rule:}

This is the most sophisticated of the common parametric decision rules because it takes into account the most variables. Both the variability of classes and the probability of a pixel belonging to each class are taken into account in calculating the distance between a candidate pixel and the mean of all classes. The basic equation for this decision rule assumes that the probabilities of a pixel being in each class are equal. However if the analyst has a priori reasons to believe that these are not equal then the probabilities can be weighted - in other words if there are good reasons to believe that a pixel is twice as likely to be sand as seagrass then the sand probability can be weighted to twice that of seagrass. a maximum decision rule with weighted probabilities is known as a Bayesian decision rule - readers interested in the mathematics of the Bayesian rule are referred to Hord (1982); Edmun (2000).

\section{Accuracy Assessment}

For knows the accuracy data result of imagery transformation and classification by the independent data, there use by confusion matrix, that such method for to account by the accuracy data result of imager analysis. Short 1982, (Purwadhi, 2001) have a formula for to assessing accuracy of the imagery data:

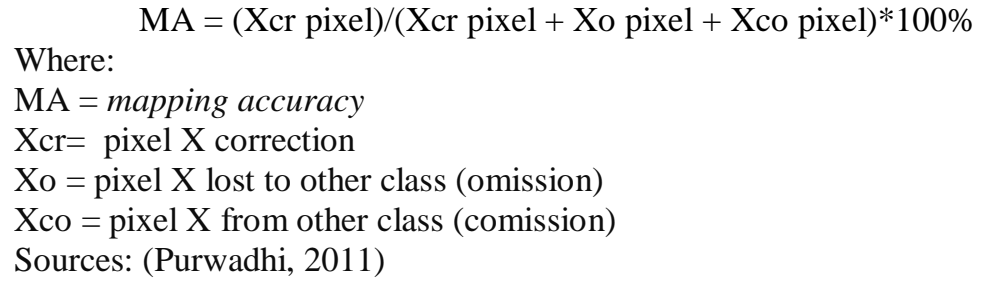$$
\mathrm{MA}=(\mathrm{Xcr} \text { pixel }) /(\mathrm{Xcr} \text { pixel }+ \text { Xo pixel }+ \text { Xco pixel }) * 100 \%
$$ 


\section{Results and Discussion}

The mangrove vegetation in the gray scale image, the appearance of mangrove, mangrove appearance on the analysis results NDVI vegetation grouping within the class in general to aspects of mangrove vegetation, and vegetation reflectance values around the mangrove many are classified into objects mangrove. Infrared Transformation II showing deep mangrove object by object contrast, it cause infrared very sensitively to biomass. Preparation of the composite image is done early before the vegetation index to recognize objects more detailed minutes prior to transformation.

Composite Imagery 432 and 543 Landsat OLI TIRS 2016.

a) Composite 432

b) Composite 543

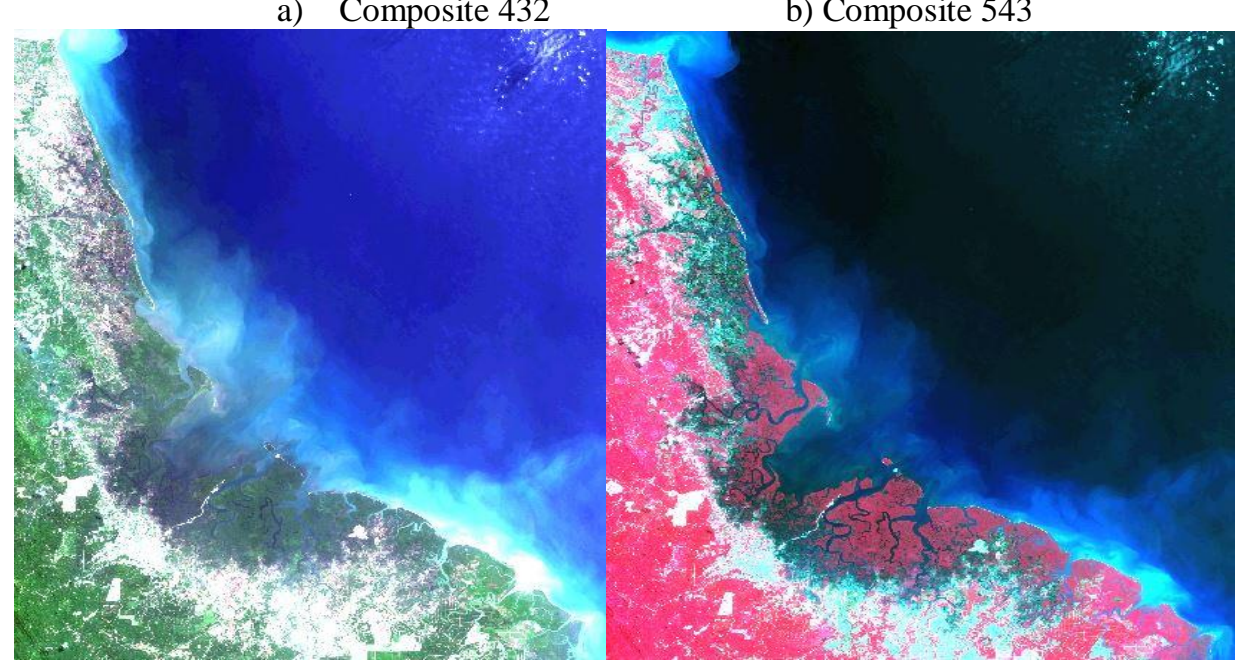

c), NDVI

d) Infrared II

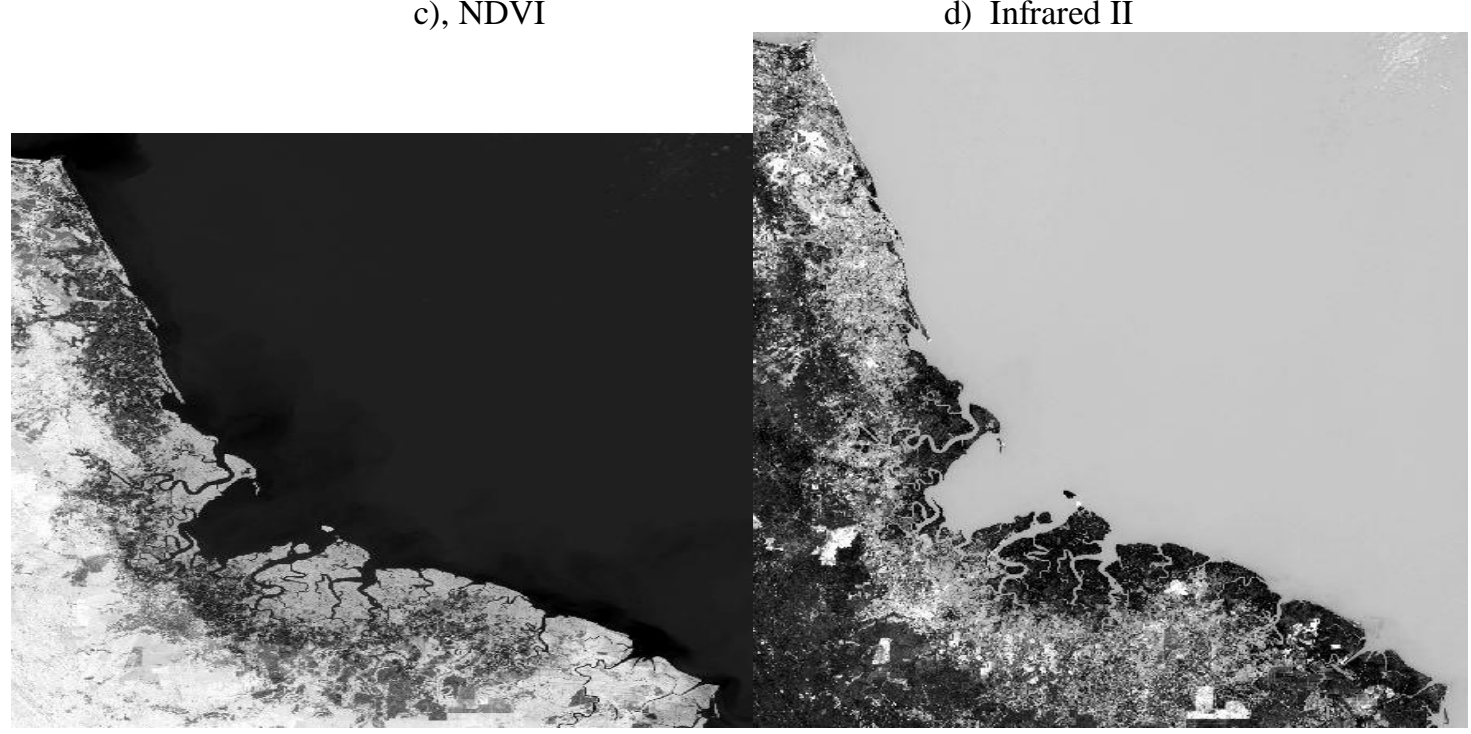




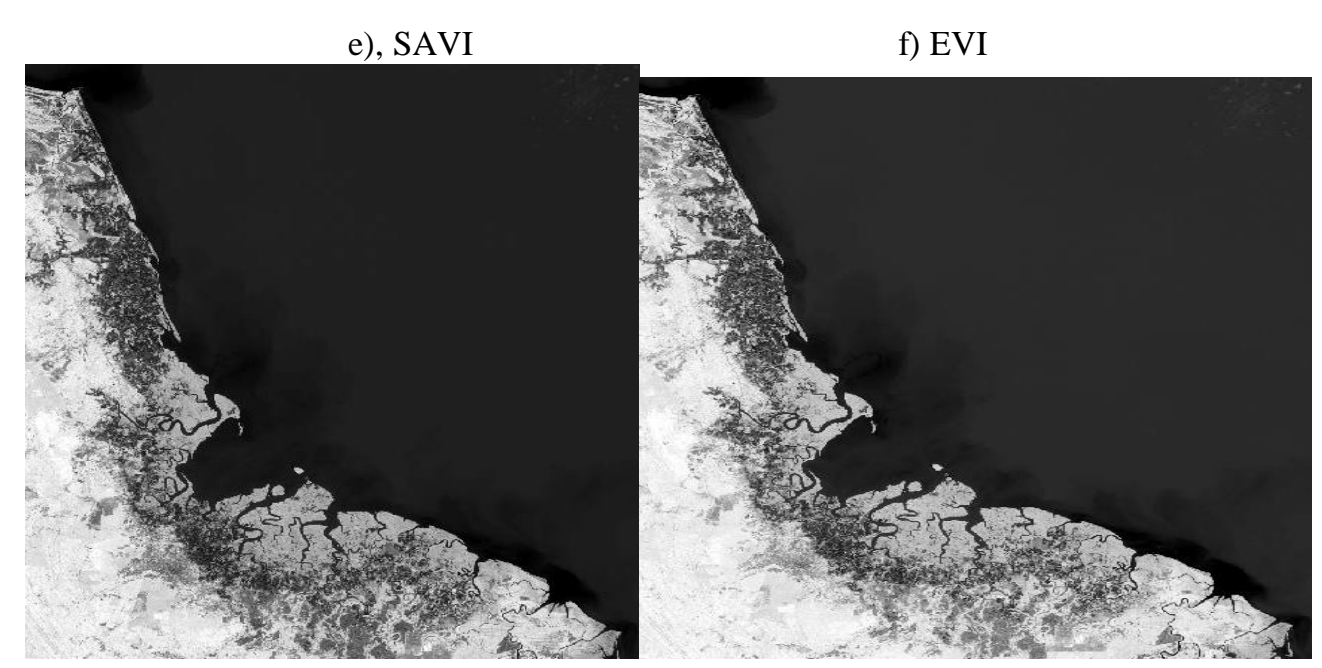

All of result vegetation index has did re classing to mangroves map, in the class we had using binary value, that 1 for mangrove area and 0 for to not mangroves, it doing for to easing do understanding the mangrove map with remove other object, and we has mangrove distribution all of gulf. The transformation algorithm is index vegetation, at of transformation NDVI, Infrared II, SAVI, EVI and Maximum Likelihood, has there funded mangroves distribution, it was has orientation surrounding at near of shoreline of coast environment, some of the mangroves growing up surrounding at tidal flat, creek and the river character. The mangrove area occupies about in the tidal flat, creek, and estuary. All of vegetation index have maximum and minimum value all of the value that difference between one and another transformation. It is cause each and another transformation have sensitively and specification. For the more detail look at table 1.

Table 1: Index Vegetation Value

\begin{tabular}{|c|c|c|}
\hline \multicolumn{3}{|c|}{ Index vegetation Value } \\
\hline & Min & Max \\
\hline NDVI & -0.18 & 0.61 \\
\hline Infrared II & -0.43 & 0.15 \\
\hline SAVI & -0.27 & 0.93 \\
\hline EVI & -0.38 & 0.72 \\
\hline
\end{tabular}

Source: Result of Analysis

Sensitivity band blue, near infrared and red waves used in multi-image transformation for mangrove mapping showed the difference of algorithm specification. On transformation NDVI vegetation in proportion, whole to the transformation of EVI object mangrove preferably in the form of vegetation zones rather dark in the image of gray scale that is on the shore line, the transformation of SAVI is similar to the result of the transformation of EVI, the difference in the vegetation not mangroves, vegetation Mangroves this transformation is quite a good response to the grouping of vegetation that is quite clear with discrimination. The ability of the transformation of vegetation in discriminating between objects vegetation and other object indicated by either of the results of the vegetation index. Contrast object variation vegetation NDVI, SAVI and EVI have higher brightness value, whereas in the second Infrared vegetation is shown in which the value of objects such vegetation. The brightness value by vegetation values generated image transformation then regrouped on research goals that serve regional distribution map mangroves. 
a), Map of NDVI

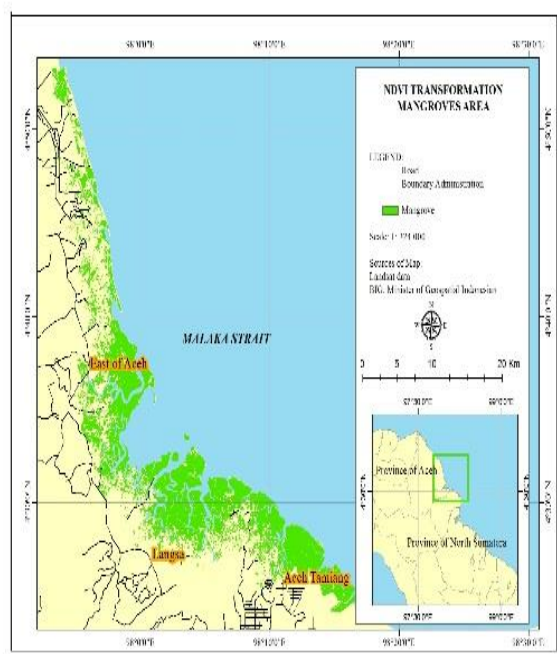

c), Map of SAVI

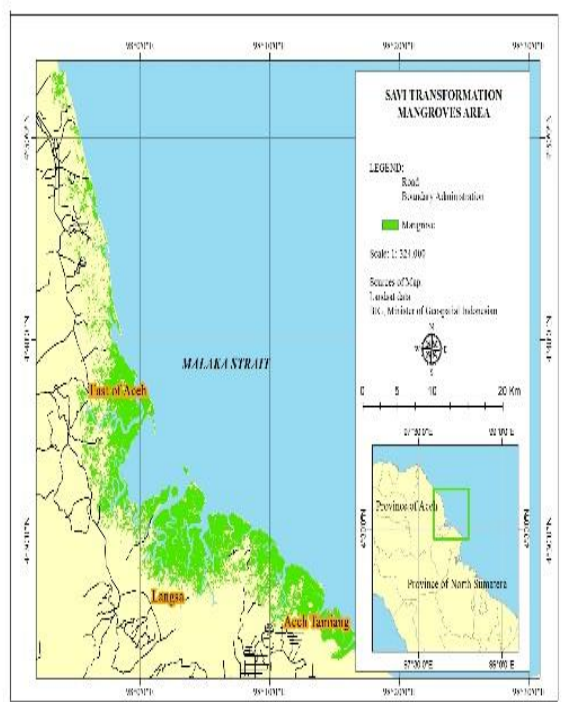

b) Map of Infrared II

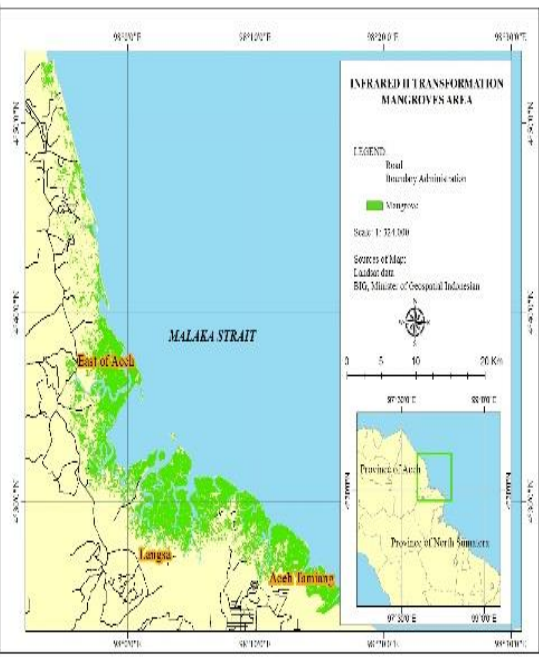

d) Map of EVI

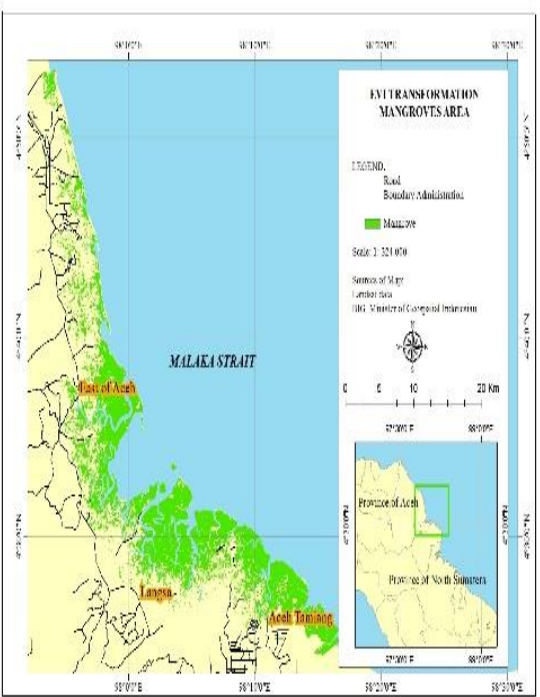

e) Map of Maximum Likelihood Classification

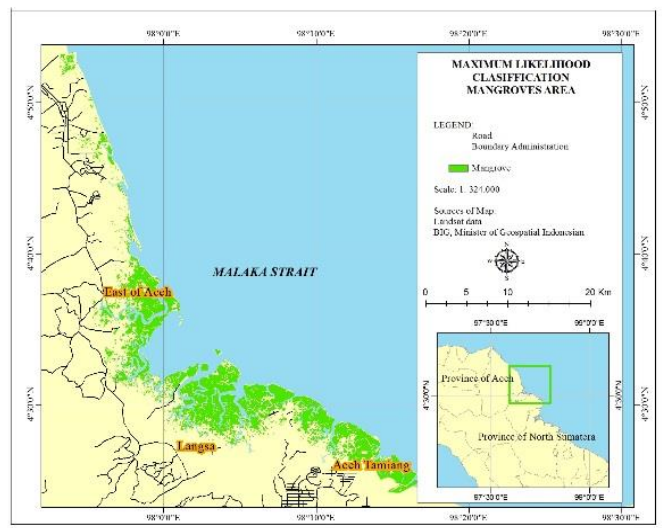


Of mangrove maps that have been converted into the form of vector data then calculate the size of the area mangrove. From each transformation has difference of value

Table 2. Matrix of Larges Mangrove Area

\begin{tabular}{|l|l|l|}
\hline & Transformation & Hectare $(\mathrm{Ha})$ \\
\hline No & NDVI & 19231.1 \\
\hline 1 & Infrared II & 19731.5 \\
\hline 2 & SAVI & 19401.7 \\
\hline 3 & EVI & 19631.9 \\
\hline 4 & Maximum Likelihood & 16231.3 \\
\hline \multicolumn{2}{|l}{ Sources: Result of Analysis }
\end{tabular}

The difference of the land area of each transformation mangrove Mahan showed differences from sensitivity of each image transformation. The contrast between the area of mangrove vegetation each image transformation in the influence of the size of image resolution for differing extents in stark contrast. Because one pixel wrong in grouping objects, the results of $30 \mathrm{~m}$ square that will be lost. The accuracy in this study by matching the data with the results of the analysis of independent data as reference data is higher details. In this study, independent data that is not used in the analysis can be referred to as variable free, while variable still is data analysis results. In this study used 204 samples in accordance with the advice Fitzpatric accuracy (1981, Mc Coy (2005) completed with the formula he suggested.

Table 3: Accuracy Assessment

\begin{tabular}{|l|l|l|l|l|l|}
\hline & NDVI & Infrared II & SAVI & EVI & $\begin{array}{l}\text { Maximum } \\
\text { Likelihood }\end{array}$ \\
\hline Overall accuracy (\%) & 84.61 & 86.36 & 86.15 & 86.36 & 81.3 \\
\hline
\end{tabular}

Sources: Analysis data

In addition interpretation of data with high-resolution images, accuracy is one of many steps to see the algorithm in detecting objects, by sampling data in the test with the results interpretation of vegetation index, found different accuracy.

\section{Conclusion}

Optimizing the used of data from Landsat satellite imagery for mapping mangrove found where sharper appearance mangrove area in the gray scale image of the results of the analysis of vegetation transformation Infrared II, compared with NDVI, but also found weaknesses of transformation Infrared II on groups of objects cloud shadows of objects very easily classified on mangrove object is seen from the results of density slicing of transformation value to classing vegetation. The percentage accuracy of image prove some dominant image transformation is able to indicate a more optimal mangrove and mangrove separating the object is not present, but the accuracy of the data analysis result has different variations, refers to the number of samples used. Sampling in accuracy tends to affect the level of accuracy. while the use of different transformation and the classification model sendri. The same thing has been stated Champbell 2002 in Danoedoro 2012. The number of samples in the study have more influence on accuracy and not overly affect the classification algorithm is used.

\section{Reference}

Cambell, J. B and R.H. Wynee. (2011). Introduction to Remote Sensing, Fifth Edition. New York: Guildford Press. ISBN 978-1-60918-176-5 
Chandran Rama, et.al. (2010). Land Remote Sensing and Global Environmental Change. New York: Springer. ISBN 978-1-4419-6748-0

Curran J. P. (1984). Geography Information System. Royal Geography Society. Jurnal: Royal Geography Society

Danoedoro, P. (2012). Introduce Digital Remote Sensing. Andi Yogyakarta. ISBN 978-979-29-3112-9

Donato C Daniel. et al.,. (2012). Mangrove Adalah Salah Satu Hutan Terkaya Karbo di Kawasan Tropis. No 12/2/ 2012. Brief

Edmun P.Green, Peter J. Mumby (2000). Remote Sensing for Tropical Costal Management. UNESCO PUBLISHING. ISBN 92-3-103736-6

Forestian,O. (2011). Estimasi Biomassa dan Kerapatan Vegetasi Mangrove Menggunakan Data Landsat ETM+. Fakultas Kehutanan Institut Pertanian Bogor(1-62)

Hanif, M. (2016). Studi Perubahan kerapatan Vegetasi Catchment Area Danau Maninjau Dengan Teknologi Penginderaan Jauh dan Sistem Informasi Geografi. Geografi. Universitas negeri Padang.

Huette, A.,C. Justice, and W. Van Leeuwen. (1999). Modis Vegetation Index. Algoritma Theorical Basic Document

Lillesand M Thomas and Kiefer W Ralph. (2004). Remote Sensing and Image Intrepetation. United States of America

Mc Coy M. Roger. (2005). Field Method in Remote Sensing. The Guildford Press: New York London.

Novianty, R., S. Sastrawibawa. S., dan J.D. Prihadi. (2011). Identifikasi Kerusakan dan Upaya Rehabilitasi Ekosistem Mangrove Di Pantai Utara Kabupaten Subang

Phihastuti, U. (2009). Pemanfaatan Sistem Informasi Geografis (GIS) dalam Pemetaan Sebaran Mangrove di Pesisir Cirebon Jawa Barat. UPI. Bandung

Prahasta, E. (2009). Sistem Informasi Geografi Konsep-Konsep dasar (Perspektif Geodesi dan Geomatika). Bandung : Informatika

Puspita, Lani, et al.,. (2005). Lahan Basah Buatan di Indonesia. Wetlands International - Indonesia Programme. Bogor

Rahmi, J. (2009).Hubungan Kerapatan Tajuk dan Penggunaan Lahan Berdasarkan Analisis Citra Satelit dan Sistem Informasi Geografis di Taman Nasional Gunung Leuser. Skripsi Departemen Kehutanan Fakultas Pertanian Universitas Sumatera Utara Medan (1- 57)

Sri Hardiyanti, P. (2001). Interpretasi Citra Digital.Jakarta: Grasin

Weng Q. (2011). Advances in Environmental Remote Sensing, Sensor, Algotihma and Applications, Indiana State Univeristy. ISBN: 978-1-4200-9181-6

\section{Muhammad Hanif}

Graduate of Geography Department, Faculty of Social Science, Universitas Negeri Padang, Indonesia hanif12jhenif@gmail.com

\section{Tommy Adam}

Student of Geography Department, Faculty of Social Science, Universitas Negeri Padang, Indonesia tommieadammaster@gmail.com 